\title{
Tuloksia eri suuruisten kalkkimäärien kokeista kiinteillä koekentillä vuoteen 1972 saakka
}

\author{
TUOMAS KERÄNEN \\ Maatalouden tutkimuskeskus, maanviljelyskemian ja-fysiikan laitos, 01300 Vantaa
}
Results from field experiments with different amounts of lime until the year 1972.

TUOMAS KERÃNEN

Agricultural Research Centre, Department of Agricultural Chemistry and Physics, 01300 Vantaa

\begin{abstract}
The main part of the liming experiments reported here consisted of experiments in which $4 \mathrm{t} / \mathrm{ha}$ ( 24 experiments and 139 harvests) and $8 \mathrm{t} / \mathrm{ha}$ (30 experiments and 182 harvests) of limestone was used. The experiments lasted on an average 6 years. The most common plants were ley harvested as hay, oats and barley. The yield increase caused by the liming of $4 \mathrm{t} / \mathrm{ha}$ was higher ( 210 food units/ha) than in the phosphate fertilization - liming experiment reported earlier (129 Fu/ha). The fertilization with $\mathrm{P}$ and $\mathrm{K}$ was in both series of experiments the same and adequate as compared with $\mathrm{N}$ application, but in the experiments reported here the amount of $\mathrm{N}$ fertilizer $(36 \mathrm{~kg} / \mathrm{ha}$ $\mathrm{N})$ was larger than in the phosphate fertilization - liming experiment $(28 \mathrm{~kg} / \mathrm{ha} \mathrm{N})$. In three experiment continuing 16-18 years the yield in the beginning decreased, but increased later nearly parallel with the amount of $\mathrm{N}$ fertilizers used. The yield response to $4 \mathrm{t}$ /ha of ground limestone was in the first 3-year period $114 \mathrm{Fu} / \mathrm{ha}$ and in the last $212 \mathrm{Fu} / \mathrm{ha}$, the response to $8 \mathrm{t} / \mathrm{ha} 154$ and $386 \mathrm{Fu} / \mathrm{ha}$ respectively. The amount of fertilizer $\mathrm{N}$ was at the beginning $16 \mathrm{~kg} / \mathrm{ha}$, and at the end $50 \mathrm{~kg} / \mathrm{ha}$. The $\mathrm{P}$ and $\mathrm{K}$ applications were adequate both at the beginning and at the end. In the light of the experimental results it has been concluded that in long-term cultivation the effect of liming appears and continues only if the plants receive all nutrients adequately and proportionately.
\end{abstract}

Vuosina 1928-38 suoritettiin eri puolilla matamme noin 500 kalkituskoetta. Maatalouskoelaitoksen maanviljelyskemian ja -fysiikan osastolle koottujen satotulosten ja siellä tehtyjen määritysten perusteella saatiin laaja selvitys kalkituksen antamista sadonlisäyksistä eri maalajeilla ja viljelyskasveilla, peltojemme happamuudesta ja vaihtuvan kalkin määrästä sekä osittain kalkin huuhtoutumisestakin (TuORILA ym. 1939). Osa kokeista sijaitsi mainitun osaston hoidossa olevilla kiinteillä koekentillä ja muutama koe jatkui vielä alussa mainitun ajan jälkeenkin. Uusia eri suuruisten kalkkimäärien kokeita, joiden tuloksia selostetaan seuraavassa, perustettiin tämän jälkeen vasta vuodesta 1948 alkaen. 


\section{Aineisto}

Koeaineiston muodostaneet kokeet on lueteltu taulukossa 1. Uusintakalkituksesta lähtien on koe katsottu uudeksi kokeeksi (kokeet 3, 12, 17, 26 ja 27). Kokeita on ollut hieta-, hiesu-, liejusavi ja turvemailla. Hietamaat sijaitsivat

Taulukko 1. Koeaineisto maalajiryhmittäin.

Table 1. Experimental material in different soil groups.

\begin{tabular}{|c|c|c|c|c|c|c|c|}
\hline \multirow[t]{2}{*}{$\begin{array}{l}\text { Koe } \\
\text { Experiment } \\
\text { No. }\end{array}$} & \multirow[t]{2}{*}{$\begin{array}{l}\text { Koepaikka } \\
\text { Site }\end{array}$} & \multirow[t]{2}{*}{$\begin{array}{l}\text { Kalkitus- } \\
\text { vuosi } \\
\text { Liming } \\
\text { year }\end{array}$} & \multirow[t]{2}{*}{$\begin{array}{l}\text { Satoja } \\
\text { kpl } \\
\text { No. of } \\
\text { yields }\end{array}$} & \multicolumn{2}{|c|}{ Maan - Soil } & \multicolumn{2}{|c|}{$\begin{array}{c}\text { Lannoitus } \\
\text { Fertilization } \\
\text { kg/ha }\end{array}$} \\
\hline & & & & & $\mathrm{mg} / 1$ & $\mathrm{~N}$ & $\mathrm{P}_{2} \mathrm{O}_{5} \quad \mathrm{~K}_{2} \mathrm{O}$ \\
\hline
\end{tabular}

Hietamaat - Sand soils

\begin{tabular}{|c|c|c|c|c|c|c|c|c|c|}
\hline 1 & V. Ahola, Lappajärvi & i $\ldots . . . \ldots \ldots \ldots . . . . . . .$. & 1956 & 5 & 5.62 & 800 & 16 & 83 & 50 \\
\hline 2 & T. Tuorila, Himanka & (................... & 1959 & 1 & 3.92 & 260 & 31 & 72 & 150 \\
\hline 3 & , & ................. & 1960 & 10 & 3.92 & 260 & 50 & 72 & 162 \\
\hline 4 & M. Hautala, Lohtaja & .................. & 1963 & 5 & 4.60 & 955 & 50 & 72 & 162 \\
\hline 5 & K. Pajunpää, Kälviä & ................... & 1963 & 4 & 5.10 & 780 & 50 & 72 & 150 \\
\hline 6 & H. Mărsylä, Himanka & $a \ldots \ldots \ldots \ldots \ldots . . . . . .$. & 1969 & 4 & 5.40 & 780 & 50 & 36 & 120 \\
\hline
\end{tabular}

Hiesut - Silt soils

\begin{tabular}{|c|c|c|c|c|c|c|c|c|}
\hline 7 & Mm-koulu, Nurmes ..................... & 1968 & 4 & 6.73 & 2210 & 50 & 36 & 60 \\
\hline 8 & Itä-Hämeen koetila, Hartola ........ & 1969 & 4 & 5.70 & 750 & 50 & 36 & 120 \\
\hline 9 & O. Jäntti, Pihtipudas .................. & 1969 & 4 & 5.74 & 750 & 50 & 36 & 120 \\
\hline & $\mathrm{Ke}$ & & & 6.06 & 1237 & 50 & 36 & 100 \\
\hline
\end{tabular}

Liejusavet - Gyttja clay soils

\begin{tabular}{|c|c|c|c|c|c|c|c|c|}
\hline 10 & N. Suominen, Nakkila ....... & 1948 & 16 & 5.23 & 565 & 22 & 44 & 84 \\
\hline 11 & K. Hakanpää, , , $\quad$,............. & 1948 & 7 & 5.18 & 750 & 16 & 45 & 80 \\
\hline 12 & ............... & 1955 & 9 & 5.18 & 750 & 27 & 43 & 87 \\
\hline 13 & J. Jokitulppo, & 1948 & 4 & 7.48 & 2760 & 16 & 44 & 80 \\
\hline 14 & T. Pirhonen, Porin mlk ............. & 1953 & 18 & 4.39 & 900 & 35 & 51 & 97 \\
\hline 15 & E. Nikkonen, Luvia .................. & 1955 & 15 & 5.10 & 1355 & 36 & 65 & 106 \\
\hline 16 & J. Uusi-Hanko, Porin mlk .......... & 1956 & 5 & 4.41 & 1755 & 21 & 108 & 98 \\
\hline 17 & , $\quad$, $\quad$........ & 1961 & 10 & 4.41 & 1755 & 48 & 58 & 116 \\
\hline 18 & P. Flycktig, & 1961 & 9 & 7.02 & 1585 & 47 & 60 & 111 \\
\hline 19 & S. Sjöblom, & 1961 & 11 & 5.82 & 1755 & 46 & 62 & 111 \\
\hline 20 & J. Issakoff, Eura ...................... & 1969 & 3 & 4.83 & 1185 & 50 & 36 & 120 \\
\hline 21 & Mustialan koulutila, Tammela .... & 1969 & 3 & 5.58 & 2180 & 50 & 36 & 60 \\
\hline
\end{tabular}

Turvemaat - Peat soils

\begin{tabular}{|c|c|c|c|c|c|c|c|}
\hline 22 & M. Kumpulainen, Pihtipudas ..... & 1929 & 5.19 & 1105 & 5 & 56 & 88 \\
\hline 23 & V. Hokkanen, Peipohja .............. & 1948 & 5.90 & 1185 & 16 & 46 & 80 \\
\hline 24 & V. Alasimi, Kälviä ................... & 1948 & 5.22 & 2605 & 16 & 36 & 80 \\
\hline 25 & V. Bragge, Kankaanpää ............. & 1950 & 4.30 & 1260 & 16 & 70 & 100 \\
\hline 26 & .............. & 1954 & 4.30 & 1260 & 36 & 69 & 120 \\
\hline 27 & ............... & 1961 & 4.30 & 1260 & 50 & 72 & 120 \\
\hline 28 & J. Korpela, Lappajärvi ............. & 1956 & 5.02 & 1030 & 12 & 52 & 31 \\
\hline 29 & P. Koskela, Alajärvi ................. & 1960 & 5.55 & 665 & 50 & 208 & 125 \\
\hline 30 & Mm-koulu, & 1962 & 5.58 & 1570 & 50 & 144 & 150 \\
\hline 31 & J. Pihlajakangas, Kälviä ............. & 1968 & 5.09 & 715 & 50 & 72 & 180 \\
\hline 32 & Pelson varavankila, Vaala .......... & 1970 & 5.00 & 1450 & 50 & 36 & 120 \\
\hline & Kesk & arvo - Mean & 5.04 & 1283 & 32 & 78 & 109 \\
\hline & Kaikki kok & keski & 5.21 & 1217 & 36 & 63 & 107 \\
\hline
\end{tabular}
All experiments, mean 
suurimmaksi osaksi Keski-Pohjanmaalla, liejusavet Satakunnassa ja turvemaat näillä molemmilla alueilla. Hieta- ja turvemaiden kentät olivat lähes poikkeuksestta erittäin happamia ja ne sisälsivät vähän vaihtuvaa kalkkia. Liejusavilla sekä happamuus että vaihtuvan kalkin määrä vaihtelivat paljon. Onkin mahdollista, että osa niistä oli kalkittu jo aikaisemmin. Kolmen hiesumaan happamuus oli vähintään tyydyttävä, mutta vain yhdessä oli runsaasti vaihtuvaa kalkkia.

Taulukkoon 1 on merkitty myös keskimääräinen vuotuinen lannoitus. Typpilannoitteena käytettiin aluksi kalkkisalpietaria, myöhemmin kalkkiam-

Taulukko 2. Koekasvien keskisadot ilman kalkitusta ja kalkituksen aiheuttama sadon lisäys (sulkeissa kalkitus tn/ha).

Koekasvit: $\mathrm{o}=$ ohra, $\mathrm{kv}=$ kevätvehnä, $\mathrm{r}=$ ruis, $\mathrm{k}=\mathrm{kaura}, \mathrm{vk}=$ vihantakaura, $\mathrm{h}=$ niittounrmi Table 2. Mean yields without liming and yield increase caused by liming (rate, tha in brackets). Crops: $\mathrm{o}=$ barley, $\mathbf{k v}=$ spring wheat, $\mathrm{r}=$ rye, $\mathbf{k}=$ oats, $\mathbf{v k}=$ green forage oats, $\mathrm{h}=$ ley for cutting

\begin{tabular}{|c|c|c|c|}
\hline $\begin{array}{l}\text { Koe } \\
\text { no } \\
\text { Expt. } \\
\text { no. }\end{array}$ & $\begin{array}{l}\text { Koekasvit } \\
\text { Crops }\end{array}$ & $\begin{array}{l}\text { Sato ry/ha } \\
\text { Yield food } \\
\text { units per } \\
\text { hectare }\end{array}$ & $\begin{array}{l}\text { Sadonlisäys, } \mathrm{ry} / \mathrm{ha} \\
\text { Yield increase, food units per hectare }\end{array}$ \\
\hline
\end{tabular}

\footnotetext{
Hietamaat - Sand soils
}

$120,3 \mathrm{~h} \ldots \ldots \ldots \ldots \ldots \ldots \ldots . . .1243$

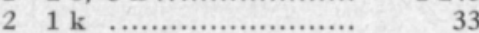

$32 \mathrm{o}, 1 \mathrm{k}, 7 \mathrm{~h} \ldots \ldots \ldots \ldots \ldots . . .6$

$42 \mathrm{o}, 3 \mathrm{~h} \ldots \ldots \ldots \ldots \ldots \ldots . . . . . . .2765$

$52 \mathrm{o}, 2 \mathrm{~h} \ldots \ldots \ldots \ldots \ldots \ldots \ldots . . . . . .2603$

$62 \mathrm{o}, 2 \mathrm{~h} \ldots \ldots \ldots \ldots \ldots \ldots \ldots . . . . . .2065$

Hiesut - Silt soils

$91 \mathrm{o}, 1 \mathrm{k}, 2 \mathrm{~h} \ldots \ldots \ldots \ldots . . .1809$

Liejusavet - Gyttja clay soils

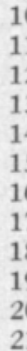

$10 \quad 2 \mathrm{kv}, 7 \mathrm{k}, 7 \mathrm{~h} \ldots \ldots \ldots \ldots$

$112 \mathrm{kv}, 5 \mathrm{k} \ldots \ldots \ldots \ldots \ldots \ldots . . . . .1250$

$123 \mathrm{k}, 6 \mathrm{~h}, \ldots$

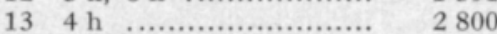

$148 \mathrm{k}, 10 \mathrm{~h} \ldots \ldots \ldots \ldots \ldots \ldots . . . . . . .1975$

$151 \mathrm{r}, 8 \mathrm{k}, 6 \mathrm{~h} \ldots \ldots \ldots \ldots \ldots . . . . .2238$

$162 \mathrm{k}, 3 \mathrm{~h} \ldots \ldots \ldots \ldots \ldots \ldots . . . . . .1782$

$176 \mathrm{k}, 4 \mathrm{~h} . \ldots \ldots \ldots \ldots . . . . . .2104$

$18 \quad 3$ o, $3 \mathrm{k}, 3 \mathrm{~h} \ldots \ldots \ldots \ldots \ldots . .1289$

$193 \mathrm{o}, 1 \mathrm{kv}, 5 \mathrm{k}, 2 \mathrm{~h} \ldots \ldots .2234$

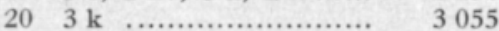

$212 \mathrm{o}, 1 \mathrm{k} \ldots \ldots \ldots \ldots \ldots \ldots \ldots \ldots . . . \ldots . .2485$

Turvemaat - Peat soils

2 vk, 7 h

$1 \mathrm{o}, 1 \mathrm{k}, 6 \mathrm{~h} \ldots \ldots \ldots \ldots \ldots . . .1922$

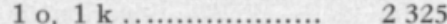

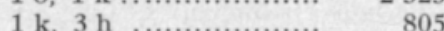

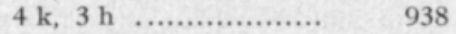

$2 \mathrm{o}, 1 \mathrm{k}, 5 \mathrm{~h} \ldots \ldots \ldots \ldots . . .1664$

$2 \mathrm{o}, 2 \mathrm{~h} \ldots \ldots \ldots \ldots \ldots \ldots \ldots . . . . . . .2589$

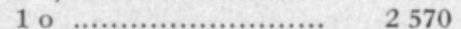

o 1 o .......................... 1930

$2 \mathrm{~h}-1938$

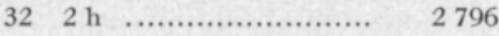

$629(2)$
$63(4)$
$859(8)$
$239(4)$
$366(4)$
$320(4)$

$320(4)$

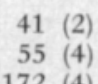

$172(4)$

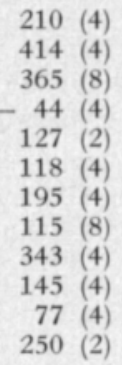

$128(5)$
$80(4)$
$-281(4)$
$200(4)$
$90(8)$
$68(12)$
$66(2)$
$10(2)$
$85(2)$
$272(4)$
$191(4)$

$\begin{aligned} 731 & (4) \\ 88 & (8) \\ 1181 & (16) \\ 174 & (8) \\ 493 & (8) \\ 291 & (8)\end{aligned}$

$953(8)$ $100(12)$

1407 (24)

$283(12)$

$341(12)$

487 (16)

$170(32)$

17 (16)

$157(16)$

$\begin{array}{rr}125(8) & 17(16) \\ -27(8) & 17(16) \\ 131(8) & 157(16)\end{array}$

$382(8)$

$577(8)$

654 (16)

$68(8)$

195 (4)

$141(8)$

$172(8)$

182 (16)

269 (8)

177 (8)

119 (8)

$29(8)$

431 (12)

648 (12)

$959(24)$

$-112(12)$

257 (8)

245 (12)

223 (12)

283 (24)

294 (16)

287 (16)

146 (16)

$337(32)$

$284(20)$

$\begin{array}{rr}109(8) & 142(12) \\ -456(8) & -\quad 4(12)\end{array}$

$-456(8)$

256 (8)

418 (16)

$294(12)$

$639(24)$

299 (36)

$199(4) \quad 265(8)$

$220(4) \quad 215(8)$

$95(4) \quad 85(8)$

$207(8) \quad 99(12)$

245 (8) 
monsalpietaria (oulunsalpietaria). Fosforilannoitus annettiin kotka- ja superfosfaattina ja kalilannoitus 40, 50 ja $60 \%$ :n kalisuolana. Typpilannoituksen määrä lisääntyi vuosina 1948 -60 16 kilosta 50 kiloon hehtaarille eli suunnilleen samoin kuin talousviljelyksilläkin. Fosforilannoituksen määrä vaihteli kokeittain ja vaihtelua lisäsi vielä muutamissa kokeissa alussa annettu peruslannoitus fosfaatilla. Kalilannoituskin vaihteli kokeittain, mutta yleensä se lisääntyi samassa suhteessa kuin kalisuolan kalipitoisuuskin. Keskimäärin oli aluslannoitus runsaampi kuin missään tähän saakka selostetussa, vähintään yhtä monta koetta ja koesatoa sisältäneessä kalkituskoesarjassa.

\section{Tulokset ja tarkastelu}

Taulukkoon 2 on merkitty kaikista kokeista saadut satotulokset. Kunkin sadonlisäystä osoittavan luvun jäljessä on sulkeissa kalkituksen määrää (tn/ha) osoittava luku. Vertaamalla maan happamuutta ja kalkkipitoisuutta (taulukko 1) todettuihin sadonlisäyksiin havaitaan, että erittäin happamissa ja vähän kalkkia sisältäneissä maissa on kalkituksella saatu sadonlisäys ollut suuri, kuten luonnollista onkin. Näissä maissa kalkkimäärän suurentaminen on yleensä vielä nostanut sadonlisäystä päinvastoin kuin vähemmän happamissa maissa.

Regressioanalyysi osoitti seuraavan riippuvuuden vallitsevan kalkkikivijauheen määrän $\left(x_{1}, \mathrm{~kg} / \mathrm{ha}\right)$ ja sadonlisäyksen ( $\mathrm{y}$, ry/ha) välillä, silloin kun maan kalkkilukua ei otettu huomioon:

$$
\begin{aligned}
& \text { Hietamaat ja hiesut }(\mathrm{n}=87) \mathrm{y}=207.50+44.787 \mathrm{x}_{1} \quad\left(\mathrm{R}^{2}=25.9 \%\right) \\
& \text { Liejusavet } \quad(\mathrm{n}=333) \mathrm{y}=148.04+12.931 \mathrm{x}_{1} \quad\left(\mathrm{R}^{2}=8.8 \%\right) \\
& \text { Turvemaat } \quad(\mathrm{n}=146) \mathrm{y}=63.65+10.297 \mathrm{x}_{1} \quad\left(\mathrm{R}^{2}=11.6 \%\right) \\
& \text { Koko aineisto } \quad(\mathrm{n}=566) \mathrm{y}=159.63+14.684 \mathrm{x}_{1} \quad\left(\mathrm{R}^{2}=8.1 \%\right)
\end{aligned}
$$

Kaikki regressiokertoimet ja selvitysasteet olivat erittäin merkitseviä $(\mathrm{P}=0.001)$. Yhtälöiden selvitysasteet olivat alhaisia. Regressioanalyysiä tarkennettaessa havaittiin maan kalkkiluvun $\left(\mathrm{x}_{2}, \mathrm{mg} / \mathrm{l} \mathrm{Ca}\right)$ huomioonottamisen parantavan yhtälöiden selvitysastetta:

$\begin{array}{llll}\text { Hietamaat ja hiesut } & y=455.31+59.264 x_{1}-0.076 x_{1} x_{2} & \left(R^{2}=39.5 \%\right) \\ \text { Liejusavet } & y=114.80+43.844 x_{1}-0.021 x_{1} x_{2} & \left(R^{2}=30.8 \%\right) \\ \text { Turvemaat } & y=58.28+33.539 x_{1}-0.018 x_{1} x^{2} & \left(R^{2}=15.5 \%\right) \\ \text { Koko aineisto } & y=141.72+50.833 x_{1}-0.030 x_{1} x_{2} & \left(R^{2}=34.8 \%\right)\end{array}$

Regressiokertoimet ja selvitysasteet olivat erittäin merkitseviä $(\mathrm{P}=0.001)$ lukuunottamatta turvemaiden $\mathrm{x}_{1} \mathrm{x}_{2}$-termin kerrointa $(-0.018)$, jonka merkitsevyys oli $\mathrm{P}=\mathbf{0 . 0 5}$.

Koska kokeita, joissa kalkitus oli alle 4 tai yli $8 \mathrm{tn} / \mathrm{ha}$, oli vähän, on taulukkoon 3 laskettu maalajeittain ilman kalkitusta saadut sadot ja vain mainituilla kalkkimäärillä saadut sadonlisäykset. Happamilla hietamailla sadonlisäys on ollut suuri, vähemmän happamilla liejusavilla keskinkertainen ja hiesuilla pieni. Liejusavia vielä happamammilla turvemailla vaikutus on jäänyt suhteellisen pieneksi, mikä on todettu aikaisemminkin (TUorILA ym. 
Taulukko 3. Ilman kalkitusta saadut sadot ja kalkituksella 4 ja $8 \mathrm{tn} /$ ha saadut sadonlisäykset ry/ha sekä maan $\mathrm{pH}$ ja vaihtuva kalkki.

Table 3. Yields without liming and yield increase caused by liming ( 4 and 8 t/ha), food units per hectare, together with soil $\mathrm{pH}$ and exchangeable lime.

\begin{tabular}{llllll}
\hline Kokeita kpl & Satoja kpl & Sato & Sadonlisäys & $\mathrm{pH}$ & $\mathrm{CaCO}_{3} \mathrm{tn} / \mathrm{ha}$ \\
No. of & No. of yields & Yield & Yield increase & & t/ha \\
experiments & & & 4 & 8 & \\
\hline
\end{tabular}

Hietamaat - Sand soils

\begin{tabular}{|c|c|c|c|c|}
\hline $5 \quad \ldots \ldots \ldots \ldots \ldots$ & 19 & 2039 & & 4.93 \\
\hline 6 ................. & 29 & 1646 & 601 & 4.76 \\
\hline
\end{tabular}

Hiesut - Silt soils

\begin{tabular}{|c|c|c|c|c|}
\hline ............... & 8 & 2446 & & 5.72 \\
\hline 3 …............ & 12 & 2403 & 94 & 6.06 \\
\hline
\end{tabular}

Liejusavet - Gyttja clay soils

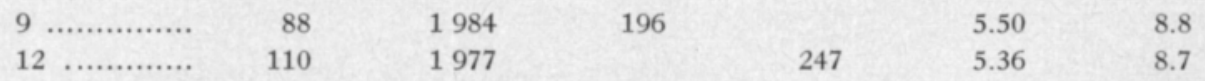

Turvemaat - Peat soils

\begin{tabular}{lllllll}
8 & $\ldots \ldots \ldots \ldots \ldots$ & 24 & 2036 & 121 & 5.24 & 7.8 \\
$9 \ldots \ldots \ldots \ldots \ldots$ & 31 & 1788 & & 125 & 5.13 & 7.8 \\
\hline
\end{tabular}

Koko aineisto - All soils

\begin{tabular}{lllllll}
24 & $\ldots \ldots \ldots \ldots \ldots$ & 139 & 2051 & 207 & 5.31 & 7.1 \\
$30 \ldots \ldots \ldots \ldots$. & 182 & 1897 & & 266 & 5.25 & 7.3 \\
\hline
\end{tabular}

Taulukko 4. Eri kasvien ilman kalkitusta saadut sadot ja kalkituksella 4 ja 8 tn/ha saadut sadonlisäykset ry/ha keskimäärin sekä maa $\mathrm{pH}$ ja vaihtuva kalkki.

Table 4. Yields without liming and yield increase caused by liming ( 4 and 8 t/ha) of different crops, food units per hectare, together with soil $\mathrm{pH}$ and exchangable lime $\left(\mathrm{CaCO}_{3}\right)$.

\begin{tabular}{|c|c|c|c|c|c|c|c|}
\hline $\begin{array}{l}\text { Kasvi } \\
\text { Crop }\end{array}$ & $\begin{array}{l}\text { Kokeita } \\
\text { kpl } \\
\text { No. of } \\
\text { exp. }\end{array}$ & $\begin{array}{l}\text { Satoja } \\
\text { kpl } \\
\text { No. of } \\
\text { yields }\end{array}$ & $\begin{array}{l}\text { Sato } \\
\text { Yield }\end{array}$ & $\begin{array}{l}\text { Sado } \\
\text { Yielc }\end{array}$ & $\begin{array}{l}\text { äys } \\
\text { crease }\end{array}$ & $\mathrm{pH}$ & $\begin{array}{l}\mathrm{CaCO}_{3} \\
\operatorname{tn} / \mathrm{ha} \\
t / h a\end{array}$ \\
\hline Ohra - Barley ......... & 12 & 21 & 2143 & 298 & & 5.56 & 7.6 \\
\hline$, \quad, \quad \ldots . . . .$. & 15 & 29 & 2053 & & 311 & 5.52 & 7.8 \\
\hline \multicolumn{8}{|l|}{ Kevätvehnä - } \\
\hline Spring wheat ............. & 3 & 5 & 1084 & 488 & 1001 & 5.41 & 5.9 \\
\hline Ruis - Rye .............. & 1 & 1 & 1800 & 150 & 250 & 5.10 & 8.0 \\
\hline Kaura - Oats ........... & 15 & 48 & 1982 & 117 & & 5.22 & 7.7 \\
\hline . $\quad \ldots . . .1 . .$. & 18 & 60 & 1852 & & 177 & 5.05 & 7.5 \\
\hline Nurmi - Ley .......... & 18 & 64 & 2067 & 185 & & 5.38 & 7.3 \\
\hline$\quad, \quad \ldots \ldots \ldots$ & 22 & 87 & 1951 & & 226 & 5.22 & 6.9 \\
\hline Koko aineisto - Whole & material & $\begin{array}{l}139 \\
182\end{array}$ & $\begin{array}{l}1994 \\
1900\end{array}$ & 210 & 278 & $\begin{array}{l}5.37 \\
5.25\end{array}$ & $\begin{array}{l}7.4 \\
7.3\end{array}$ \\
\hline
\end{tabular}


1939). Maalajeittain laskettuihin satotuloksiin vaikuttavat maan ominaisuuksien ohella myös koekasvit.

Koekasveina oli 32 kokeessa yhteensä 31 ohraa, 5 kevätvehnää, 1 ruis, 64 kauraa, 2 vihantakauraa, 96 nurmea eli yhteensä 199 satoa. Käytettyjen kalkkimäärien suuren vaihtelun takia on satotuloksista vaikea saada aikaisemmin esitettyjen tulosten kanssa vertailukelpoista yhdistelmää. Sellainen on tehty kasvilajeittain taulukkoon 4 kalkituksilla 4 ja 8 tn/ha. Se edustaa vastaavasti 139 ja 182 koesatoa. Suurin sadonlisäys on saatu ohralla ja kevätvehnällä, seuraavaksi suurin rukiilla (1 koesato) ja nurmilla ja pienin kauralla. Tässä suhteessa tulokset poikkeavat aikaisemmista vain vehnällä, mutta kokeiden pienen lukumäärän takia eivät tulokset vaikuta paljon kaikkien kasvien keskiarvoon. Keskiarvoissa tasoittuvat kaikkia kasveja edustavat kenttien $\mathrm{pH}$-luvut ja vaihtuvan kalkin määrät. Ne tulevat myös lähelle niitä lukuja, jotka on esitetty aikaisempien laajojen kalkituskoesarjojen tulosten yhteydessä (Tuorila ym. 1939, Keränen ja Marjanen 1970, 1972). Niiden ja esillä olevan koesarjan tulosten vertailu on esitetty seuraavassa:

Sadonlisäys kalkituksella Lannoitus $\mathrm{kg} / \mathrm{ha}$

$4 \mathrm{tn} / \mathrm{ha} \quad 8 \mathrm{tn} / \mathrm{ha} \quad \mathrm{N} \quad \mathrm{P}_{2} \mathrm{O}_{5} \quad \mathrm{~K}_{2} \mathrm{O} \quad \mathrm{K}_{2} \mathrm{O}: \mathrm{N}$

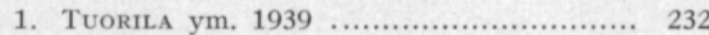

2. Keränen ja Marjanen $1970 \ldots \ldots \ldots \ldots \ldots \ldots . .206$

274

3. Keränen ja Marjanen 1972 ................. 129

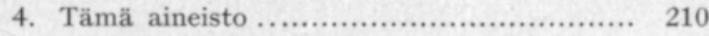

302

$-$

278

$\begin{array}{rrrr}- & - & - & \\ - & - & - & \\ 28 & 62 & 84 & 3.0 \\ 36 & 63 & 107 & 3.0\end{array}$

Kahdessa ensimmäisessä sarjassa oli viljelijäin antama lannoitus. Lannoituksen määrää ei tunneta. Ottaen huomioon ko. ajankohtien väkilannoitteiden yleisen käytön voidaan otaksua, että lannoitus oli pienempi kuin sarjoissa 3 ja 4 . Sarjassa 4 vastaa esitetty aluslannoitus kalkitusta $8 \mathrm{tn} /$ ha, mutta kalkituksella $4 \mathrm{tn} / \mathrm{ha}$ oli sekä $\mathrm{P}_{2} \mathrm{O}_{5}$ - että $\mathrm{K}_{2} \mathrm{O}$-määrää vain $3 \mathrm{~kg} / \mathrm{ha}$ pienempi.

Tulosten vertailussa pääpaino on heinällä, kauralla ja ohralla, joita kaikissa koesarjoissa oli jokseenkin samassa suhteessa. Fosfaattilannoituskalkituskokeissa (3) kalkituksen (4 tn/ha) antama sadonlisäys oli runsaasti puolet kolmessa muussa sarjassa saadusta lisäyksestä. Fosfaattilannoitus-kalkituskokeiden tulosten esittäjät otaksuivat, että runsas fosfori- ja kalilannoitus oli pienentänyt kalkin vaikutusta, minkä fosforin suhteen on todennut SALONEN (1953) ja molempien ravinteiden suhteen PERsson (1970).

Esillä olevan koesarjan kolmen pitkäaikaisimman kokeen tulokset viittaavat siihen, että myös typpilannoituksella on suuri vaikutus kalkituksella saatuun sadonlisäykseen. Näissä kokeissa (no 10, 14 ja 15) oli typpilannoitus aluksi 15,5 , myöhemmin $50 \mathrm{~kg} /$ ha. Ne kaikki jatkuivat vähintään 16 vuotta kalkituksen jälkeen, sillä vaikka kokeesta no 15 korjattiin vain 15 koesatoa, niin se oli ollut yhden välivuoden laitumena, jolloin satoa ei voitu punnita. Kun jätetään laskuista pois kokeen no 10 alussa viljellyt kaksi kevätvehnää, joiden sato oli erittäin pieni ja sadonlisäys kalkituksella suuri sekä kokeen no 15 ruis, oli kokeissa 23 kauraa ja 23 nurmea, jotka jakautuivat lähes tasan kunkin kokeen osalle (taulukko 2). Kokeista saadut kauran ja heinän keskimääräiset tulokset kolmivuotiskausittain sekä niitä vastaava typpilannoitus on 


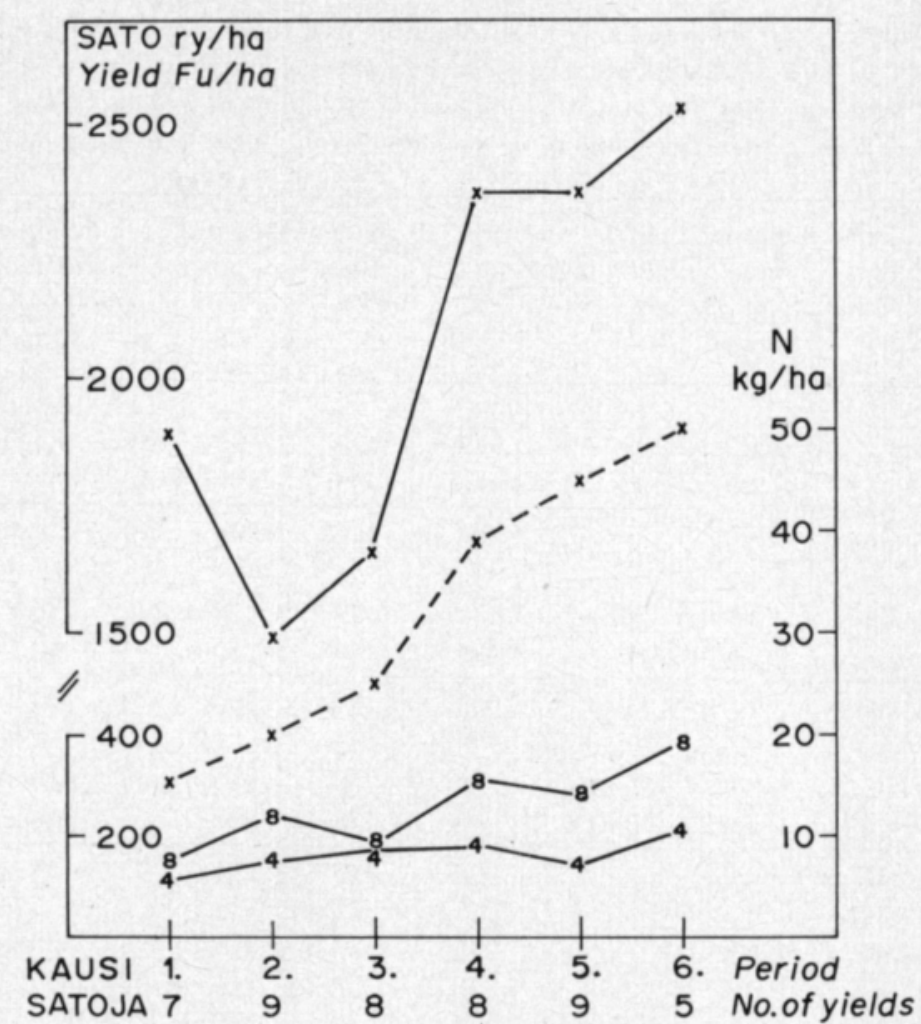

Kuva 1. Kauran ja heinän keskimääräinen sato kolmivuotiskausittain sekä vastaava typpilannoitus.

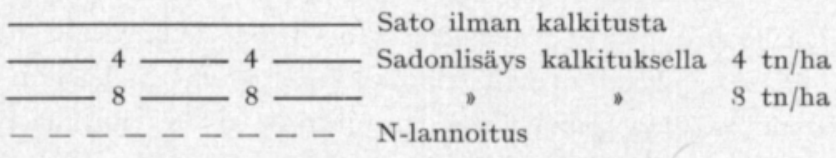

Fig. 1. Mean yield of oats and ley in 3-year periods and corresponding $N$ fertilization.

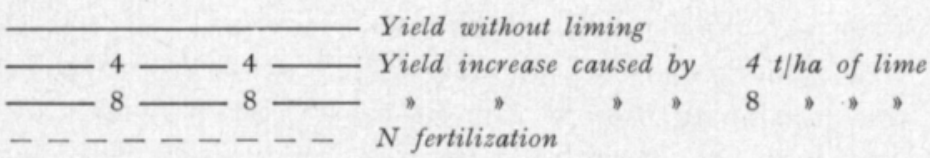

esitetty kuvassa 1. Heinää ei tosin viljelty ensimmäisellä kaudella, mutta asiallisesti sama tulos saataisiin yksinomaan kauralla (taulukko 5). Kuvassa 1 esitettyjen lukujen mukaan satotaso aluksi jopa alentui ja alkoi myöhemmin nousta jokseenkin samassa suhteessa kuin typpilannoituskin. Sadonlisäys molemmilla kalkkimäärillä oli aluksi pieni ja lisääntyi koeajan loppuun mennessä pienemmällä määrällä kaksinkertaiseksi (114-212 ry/ha) ja suuremmalla määrällä vielä enemmän (154-386 ry/ha). Fosforilannoitus pysyi koeajan kuluessa samana ja oli nykyisten, koetuloksiin perustuvien tietojen mukaan vielä koeajan lopussakin riittävä. Typpilannoitus lisääntyi vastaavasti 3,2kertaiseksi ja kalilannoitus 1,4-kertaiseksi. Koeajan alussa oli kalin ja typen suhde $\left(\mathrm{K}_{2} \mathrm{O}: \mathrm{N}\right) \quad \mathbf{5 , 4}$ ja lopussa $2, \mathbf{5}$. 
Taulukko 5. Kauran ja heinän sadot ja kalkituksella 4 ja 8 tn/ha saadut sadonlisäykset ry/ha kokeissa 10, 14 ja 15 kolmella alku- ja kolmella loppukaudella sekä vastaava lannoitus.

Table 5. Oats and ley yields and yield increase caused by liming (4 and 8 t/ha) in experiments 10, 14 and 15 in three periods in the beginning and three periods at the end and NPK fertilization.

\begin{tabular}{|c|c|c|c|c|c|}
\hline Koekasvi & Satoja & Kausi & Sato & Sadonlisäys & Lannoitus $\mathrm{kg} / \mathrm{ha}$ \\
\hline \multirow[t]{2}{*}{ Crop } & kpl & Period & Yield $\left.^{\mathbf{1}}\right)$ & Yield increase & Fertilization $\mathrm{kg} / \mathrm{ha}$ \\
\hline & yields & & & 4 & $\mathrm{P}_{2} \mathrm{O}_{5} \quad \mathrm{~K}_{2} \mathrm{O} \mathrm{K} \mathrm{K}_{2} \mathrm{O}: \mathrm{N}$ \\
\hline
\end{tabular}

\begin{tabular}{|c|c|c|c|c|c|c|c|c|c|}
\hline Kaura - Oats ...... & 12 & $1-3$ & 1939 & 118 & 198 & 18 & 61 & 84 & \\
\hline Heinä - Ley ...... & 12 & $2-3$ & 1645 & 174 & 187 & 23 & 47 & 85 & \\
\hline Keskiarvo - Mean & & & 1792 & 146 & 193 & 20 & 54 & 84 & 4.2 \\
\hline Kaura - Oats ...... & 11 & $4-6$ & 2632 & 173 & 326 & 42 & 59 & 104 & \\
\hline Heinä - Ley ........ & 11 & $4-6$ & 2184 & 198 & 280 & 45 & 49 & 113 & \\
\hline Keskiarvo - Mean & & & 2408 & 186 & 303 & 43 & 54 & 108 & 2.5 \\
\hline Kaura - Oats ...... & 23 & $1-6$ & 2270 & 144 & 259 & 30 & 60 & 93 & \\
\hline Heinä - Ley ........ & 23 & $2-6$ & 1903 & 186 & 232 & 34 & 38 & 98 & \\
\hline Keskiarvo - Mean & & & 2086 & 165 & 245 & 32 & 54 & 96 & \\
\hline
\end{tabular}

1) food units per hectare

Useiden koetulosten (Brummer 1959, SAlonen ym. 1962, Keränen ja TAINio 1968) perusteella voidaan päätellä, että silloin kuin fosfori- ja kalilannoitus on riittävä, satotaso määräytyy pääasiassa typpilannoituksen mukaan. Fosforilannoitus on ollut typpilannoitukseen nähden riittävä, 2--4-kertainen $\left(\mathrm{P}_{2} \mathrm{O}_{5}: \mathrm{N}\right)$. Kalilannoituksen suhteen on 1,6 -kertainen kalilannoitus osoittautunut riittäväksi karkeilla kivennäismailla jatkuvassa viljelyssä (KERÄNEN 1968). On ilmeistä, että esimerkiksi 1940- ja 1950-luvuilla perustetuissa kalkituskokeissa, jolloin oli vähemmän tietoja lannoituksessa tarvittavien pääravinteiden määristä ja suhteista, typpilannoitus tuli minimitekijäksi, eikä riittänyt täysin kalkituksen vaikutuksen esille tuloon. Niinpä fosfaattilannoitus-kalkituskokeissa (KERÄNEN ja MARJANEN 1972) ja nyt esitetyissa kokeissa kalkituksella $4 \mathrm{tn} / \mathrm{ha}$ saadun sadonlisäysten eron, $81 \mathrm{ry} / \mathrm{ha}$, selittänee ainakin osaksi viimeksi mainittujen saama $8 \mathrm{~kg} /$ ha suurempi typpilannoitus (vrt. s. 190). Täysi varmuus asiasta saataisiin vain pitkäaikaisilla kenttäkokeilla, joissa on myös ueampia typpilannoitustasoja. Todennäköisenä voidaan kuitenkin pitää, että pitkäaikaisessa viljelyssä pääsee kalkituksen vaikutus täysin esille ja jatkuu vasta silloin, kun kasvit saavat riittävästi ja tasapainoisesti kaikkia ravinteita. 
Kalkituskoesarjan pääosan muodostivat ne kokeet, joissa kalkitus oli 4 (24 koetta ja 139 koesatoa) ja 8 tn/ha (30 koetta ja 182 koesatoa) kalkkikivijauhetta. Kokeet jatkuivat keskimäärin noin 6 vuotta. Pääosan koekasveista muodostivat heinäksi korjattu nurmi, kaura ja ohra. Kalkituksella 4 tn/ha saatu sadonlisäys (210 ry/ha) oli suurempi kuin aikaisemmin esitetyissä fosfaattilannoitus-kalkituskokeissa (129 ry/ha). Fosfori- ja kalilannoitus olivat molemmissa kokeissa jokseenkin yhtä suuret ja typpeen nähden riittävät, mutta tässä selostetuissa kokeissa oli typpilannoitus (36 kg/ha N) suurempi kuin fosfaattilannoitus-kalkituskokeissa $(28 \mathrm{~kg} /$ ha N). Kolmessa $16-18$ vuotta jatkuneessa kokeessa kauran ja heinän satotaso aluksi jopa laski, mutta nousi myöhemmin jokseenkin samassa suhteessa kuin typpilannoitus. Kalkituksella $4 \mathrm{tn} /$ ha oli sadonlisäys ensimmäisenä kolmivuotiskautena $114 \mathrm{ry} / \mathrm{ha}$ ja viimeisenä $212 \mathrm{ry} / \mathrm{ha}$, kalkituksella $8 \mathrm{tn} / \mathrm{ha}$ vastaavasti $154 \mathrm{ja} 386 \mathrm{ry} / \mathrm{ha}$. Typpilannoitus oli alussa 16 ja lopussa $50 \mathrm{~kg} / \mathrm{ha}$ ja fosfori- ja kalilannoitus typpeen nähden sekä alussa että lopussa riittävät. Koetulosten nojalla on päätelty, että pitkäaikaisessa viljelyssä pääsee kalkituksen vaikutus täysin esille ja jatkuu vasta silloin, kun kasvit saavat riittävästi ja tasapainoisesti kaikkia ravinteita.

\section{KIRJALLISUUTTA}

BRUMmer, V. 1959. Lannoituksen vaikutuksesta sokerijuurikkaan satoon. Summary: Effect of fertilization on the yield of sugar beet. Suom. Maatal.tiet. Seur. Julk. 94: 201-236.

KERĀNEN, T. 1968. Kalilannoitus-kalkituskokeiden tuloksia hieta- ja savimailla. Koetoim. ja Käyt. 25: 29, 32.

_ - \& MARJANEN, H. 1970. Kalkituksen vaikutus ja kannattavuus. Koetoim. ja Käyt. 27: $10-11$.

- - \& MarJanen, H. 1972. Kalkitus ja fosfaattilannoitus. Paikalliskokeiden tuloksia 1940-, 1950-, ja 1960-luvulta. Referat: Kalkning och fosfatgödsling. Resultat i lokala fältfärsök under 1940-, 1950-, och 1960-talen. Kehittyvä Maatalous 6, 1972.

_, \& TAInio, A ( $\dagger)$. 1968. Hiesu- ja savimaiden kalilannoitustarpeesta. Zusammenfassung: Über den Kalidüngungsbedarf von Lehm- und Tonböden. Ann. Agric. Fenn. 7: $161-174$.

Persson, J. 1970. De permanenta kalkningsförsöken. Växtnäringsnytt 26, 4: 23-28.

SAlonen, M. 1953. Peruslannoituskokeita superfosfaatilla. Summary: Store dressing experiments with superphosphate. Valt. Maatal.koetoim. Julk. 139: 1-40.

- -, TAINı́, A. \& TÄhtrnen, H. 1962. Typpilannoitusta koskevia tutkimuksia. Selostus kiinteillä koekentillä v. 1928-1960 suoritetuissa eri typpimäärien kokeissa saaduista tuloksista. Summary: Investigations of nitrogen fertilization. Ann. Agric. Fenn. 1: 133-174.

TUORILA, P., TAINio, A. \& TeräsvUori, A. 1939. Suomen viljelysmaiden kalkitustarpeesta. Valtion maatalouskoetoiminnan tuloksia vuosilta 1928-38. I osa. Referat: Úber den Kalkdüngungsbedarf der finnischen Böden. Ergebnisse der staatlichen landwirtschaftlichen Versuchstätigkeit von den Jahren 1928-38. Erster Teil. Valt. Maatal.koetoim. Julk. 104: 1-529. 